\title{
G1/S-Specific Cyclin-D1
}

National Cancer Institute

\section{Source}

National Cancer Institute. G1/S-Specific Cyclin-D1. NCI Thesaurus. Code C17988.

G1/S-specific cyclin-D1 (295 aa, $34 \mathrm{kDa}$ ) is encoded by the human CCND1 gene. This protein is involved in the regulation of the G1/S transition of the cell cycle. 